\title{
The Effect of Islamic Social Reporting Disclosure and Company Reputation on Financial Performance with Business Ethics as a Moderating Variable
}

\author{
Helliana* \\ Doctoral Program in Economics, Concentration in Accounting \\ Faculty of Economics and Business, Trisaksi University, Jakarta \\ Khomsiyah \\ lecturer Doctoral Program in Economics, Concentration in Accounting \\ Faculty of Economics and Business, Trisaksi University, Jakarta
}

\begin{abstract}
One of the company's activities in carrying out its social activities according to an Islamic perspective is the Islamic Social Reporting disclosure. Companies that carry out social activities also aim to maintain the company's reputation. This study will analyze the effect of Islamic Social Reporting disclosure and company reputation on financial performance. The variables of Islamic Social Reporting disclosure and company reputation are moderated by business ethics. The research method used is descriptive method using the verification method approach. The sample used in this study were 11 Islamic banks in Indonesia that published annual reports from 2012-2016. The results showed that the Islamic Social Reporting Disclosure variable and the Islamic Social Reporting Disclosure variable which were moderated by business ethics had a significant effect on financial performance. Meanwhile, the company reputation variable and the company reputation variable which were moderated by business ethics did not significantly affect financial performance. In addition, business ethics as a moderating variable strengthens the influence of Islamic Social Reporting Disclosure and company reputation on financial performance. Islamic Social Reporting Disclosure variables and company reputation have a negative impact on company performance in Islamic banking because Islamic banking runs its operations emphasizing social aspects and providing greater benefits to the environment. Business ethics has a positive influence on the Islamic Social Reporting Disclosure variable and company reputation in Islamic banking so that Islamic banks that have good business ethics have better financial performance.
\end{abstract}

Keywords: Islamic social reporting disclosure, company reputation, business ethics and financial performance DOI: $10.7176 /$ RJFA/11-24-07

Publication date: December $31^{\text {st }} 2020$

\section{Introduction}

Indonesia is a country with the largest Muslim population in the world. Indonesia should become a pioneer for the development of Islamic finance in the world. Indonesia's potential to become a global player in Islamic finance is very large, because the large Muslim population can become a potential customer of the Islamic finance industry and also has bright economic prospects. This can be seen from the relatively high economic growth (in the range of $6.0 \%-6.5 \%$ ) which is supported by solid economic fundamentals and the increase in Indonesia's sovereign credit rating to investment grade which will increase investors' interest in investing in the domestic financial sector. including the Sharia finance industry (Hasan, 2015). The Bank Indonesia report (2019) states that in line with the Indonesian economy in general, the Sharia economy is still resilient, supported by domestic demand amid a decline in exports due to the global economic slowdown. One of them is supported by the priority sector in the halal value chain (HVC) where the performance of the Islamic economy is generally higher than the national GDP with growth reaching 5.72\% (Indonesia, 2019). In addition, the Indonesian state has abundant natural resources which can be used as underlying transactions for the Islamic financial industry (Hidayat, 2018). Therefore, Indonesia has great potential in Sharia finance.

Indonesia is a country that has great potential for the development of the Sharia financial industry where based on a report from Edbiz Consulting (2020), Indonesia ranks first as the highest economic country with an Islamic Financial Country Index (IFCI) value of 81.93 above Malaysia, Iran, Arabia. Arabia and Sudan (Consulting, 2020). The indicators used to measure IFCI consist of (1) Number of Islamic Banks (2) Number of Islamic banking or non-banking institutions involved in the IBF (3) Number of Sharia Supervisors (4) Islamic Financial Assets (5) Muslim Population (6) Sukuk ( 7) Education \& Culture (8) Islamic Regulation \& Law (Consulting, 2020). Based on this, one of the factors that determine the Islamic financial value of a country is Islamic banking or Sharia banking.

National Sharia banking is a financial institution and organization operating in Indonesia which is now required to run its business according to Sharia principles (Budiono, 2017). In order for a Sharia bank to survive 
and compete in this day and age, Sharia banks must have good financial performance. Factors that affect financial performance include company compliance in implementing Sharia, where company activities are religiously approved and liquidity and leverage have a positive effect on financial performance by increasing return on assets (ROA) and return on sales (ROS) (Pepis \& de Jong, 2019). Equity, bonds and corporate securities have an important effect on Sharia finance (Uddin et al., 2019). Profitability, debt to asset ratio, and size have a positive impact on financial performance in agricultural cooperatives in the United States (Pokharel et al., 2020). Gender equality affects financial performance in several countries (Nguyen et al., 2020). Disclosure of the company's environmental concern activities can improve the financial performance of companies listed on the Shanghai and Shenzhen China stock exchanges (Wang et al., 2020). Economic wealth, market liquidity, and strong institutional board size have a positive influence on the financial performance of Sharia companies (Stefano \& Kok, 2020). In achieving these factors, companies must carry out economic activities that support them.

Other factors affecting the company's financial performance include the quality of corporate governance by putting pressure on managers to work so as to reduce the company's capital and risk (Ullah et al., 2020), concern for the environment (Jan et al., 2019; Wang et al., 2020) innovating information disclosure with the latest technology (Xia \& Wang, 2020), carrying out sustainable management efficiency (Jan et al., 2019), conducting socially responsible investment (SRIs) in Sharia to lead to development sustainable companies (Charfeddine et al., 2016; Yesuf \& Aassouli, 2020), undertaking corporate social responsibility (Darus et al., 2017; Jan et al., 2019), conducting Islamic Social Reporting (ISR) to maintain sustainability corporate finance (Asriati et al., 2016; Cahya, 2018; Hadinata, 2019; Hartini, 2018; Indrawaty \& Wardayati, 2016; Jan et al., 2019; Rizfani \& Lubis, 2019; Santoso \& Dhiyaul-Haq, 2017; Shakeela \& Weaver, 2018), and maintaining the company's reputation so that it remains good in front of stakeholders (Shim \& Yang, 2016; Zraková et al., 2017) and social media (Walsh et al., 2016), policy government related to pollution which must be environmentally friendly (Petitjean, 2019), and business ethics carried out by Eurotravel which affects the convenience of its customers so that it affects the company's finances (Vidgen et al., 2020). This study will analyze Islamic Social Reporting (ISR), company reputation, and business ethics as factors that affect the company's financial performance.

In carrying out their ethical business and social activities, sharia companies and institutions such as sharia banking can use standard items of CSR disclosure that are in accordance with the Islamic perspective summarized in the ISR concept. ISR is a way of fully disclosing the condition of a company entity in an Islamic context (Cahya, 2018). The ISR concept is expected to form accounting practices that are in accordance with Islamic law so as to make a meaningful contribution to economic progress and more honest and fair trade and business practices. Therefore, the public needs to know an information or disclosure from a company according to their needs based on the principles of Islamic law. In the Islamic context, the public has the right to know various information about organizational activities (Cahya, 2018). In the Islamic perspective, Allah SWT has explained in his words regarding social responsibility to fellow living beings in Surah Al-Baqarah verse 177 which one of the excerpts means (Asriati et al., 2016)

“....giving the property he loves to relatives, orphans, poor people, people who are traveling (travelers)..." (Qur'an, 2:177)

from this verse it can be concluded that Islam prioritizes social values rather than just performing prayers, because the Al Quran emphasizes that faith will not be perfect without being accompanied by social practices in the form of concern for the welfare of those in need. In addition, the company's obligations related to social care are stipulated in Law No.40 of 2007 concerning Limited Liability Companies Chapter IV, article 66 paragraph 2c and Chapter V, article 74 where the company's annual report must reflect social responsibility, even companies whose business activities are in the field and / or related to natural resources must carry out social responsibility (Asriati et al., 2016). Therefore, Sharia companies are required to carry out ISR because this can alleviate social problems both in business and community entities (Cahya, 2018), knowing the size of the business of a company (Hartini, 2018), the company's financial growth in Sharia (Hadinata, 2019; Indrawaty \& Wardayati, 2016), changing the paradigm of society which states that tourism is a crime (Shakeela \& Weaver, 2018), has a positive effect on corporate performance awards (Santoso \& Dhiyaul-Haq, 2017), and company annual reports in Jakarta Islamic Index (JII) (Rizfani \& Lubis, 2019). According to Fitria and Hartanti (2010: 4), measurement guidelines for ISR disclosure use the ISR Index (Asriati et al., 2016). The ISR Index is a benchmark for the implementation of Islamic banking social responsibility which contains a compilation of CSR standard items set by the Accounting and Auditing Organization for Islamic Financial Institutions (AAOIFI) (Cahya, 2018). In this study, measurement of the ISR uses dimensions and indicators made by Maali et. all. (2006) using the dummy method for Islamic banks in six countries (Santoso \& Dhiyaul-Haq, 2017). The ISR disclosure used in this study is the ISR disclosure that uses content analysis by combining narrative, value, and visual images. Smith (2007) and Olesen (2012) state that in measuring the content analysis of the ISR disclosure, the researcher uses a rating of 0,1,2,3 (Susanti \& Nurhayati, 2014).

Apart from ISR, what can affect the company's financial performance is the company's reputation (Shim \& Yang, 2016; Zraková et al., 2017). Fombrun (1996) defines a company's reputation as a collective collection of 
holding beliefs about a company's ability and willingness to satisfy various stakeholders (Ali et al., 2020). The company's reputation provides sustainable competitiveness and profit for the organization. The company's reputation can be a protector of the company's activities from various external circumstances (Ali et al., 2020). Building a company's reputation is not short, it takes a long time. According to Schwartz (2013), young companies must actively participate in legitimizing companies through competence, innovation and accelerated incubation programs (Bruna \& Nicolò, 2020). In addition, young companies are required to meet customer demands in maintaining the company's reputation which must meet the criteria of compliance, accountability, efficiency, scalability, viability, managerial law and professional standards (Bruna \& Nicolò, 2020). Eberl \& Schwaiger (2005) stated that a strong company reputation has a positive impact on future financial performance (Kuranovic, 2018). A strong company reputation positively affects the success of the relationship between the organization and the client. In this era, the company's reputation is influenced by the involvement and disclosure of corporate information on social media (Ji et al., 2017; Walsh et al., 2016). The use of social media by company employees can have an impact on the company's reputation. Employees who are not careful in using social media can harm the company's reputation (Walsh et al., 2016). Based on this, the company's reputation can indirectly affect the company's financial finances. In this study, the measurement of company reputation uses dimensions and theoretical indicators from Picton and Broderick (2001) (Hardiani, 2016). Picton and Broderick (2001) explain that there are six factors that can be used to measure the reputation of a company, namely (1) Dynamic (2) Cooperative (3) Wise (4) Characteristic (5) Successful and (6) Able to Refrain (Hardiani, 2016).

The company's activities in doing business will have a positive and negative impact on the output and outcome of the company. When realizing that the negative impact of business activities on the survival of mankind, efforts to reconcile ethical views and business views from time to time are always campaigned in order to obtain the most ideal model, namely business ethics. The rapid development of business causes business people to be more profitoriented, as a result, humans as business actors are marginalized from their human values, so humans must be aware that business ethics is needed to overcome these problems (Rodhiyah, 2011). According to Ferrel et. all (2009), ethics-based business will run without harming other parties

"Understanding what is right or wrong and acceptable or unacceptable based on organizational and societal expectations constitutes business ethics. It is an area that will shape business activity ever more in the 21 st century."

Business ethics is understanding what is right or wrong and acceptable or unacceptable based on the expectations of the organization and society which is the definition of Business Ethics (Mulyaningsih \& Hermina, 2017). Companies that carry out good business ethics can improve the business continuity of their companies in a sustainable manner (Ramboarisata \& Gendron, 2019), keep online business activities in accordance with the prescribed rules (Vidgen et al., 2020), and maintain the attitude of employees who work not harm the company (Hernández-López et al., 2020). In this study, business ethics is measured using the measurement results of Han Dongker et al. (2008) which identified 10 factors contained in a company code of ethics (Yahfizham, 2013).

This study will analyze the effect of ISR and company reputation on financial performance. This influence is moderated by business ethics. Financial performance is measured by profitability, namely the calculation of return of equity (ROE). The ISR that is carried out will be analyzed how much it affects financial performance by using measurements made by Smith (2007) and Olesen (2012), which states that in measuring the ISR disclosure content analysis the researcher uses a dummy (Susanti \& Nurhayati, 2014). For company reputation, this study will measure the company's reputation performance using the results of research by Picton and Broderick (2001) which use 6 (six) measurement factors (Hardiani, 2016). For business ethics, the measurement used by Han Dongker et al. (2008) uses 10 factors to measure the company's code of ethics (Yahfizham, 2013). The newest thing from this research is the use of business ethics as a moderating variable where companies that apply business ethics can strengthen or weaken the company's financial performance. The population used is Islamic banks in Indonesia. The results of this study are expected to become knowledge for Islamic banking to optimize all company activities related to social concern, company reputation and business ethics so as to improve company performance, especially in Sharia.

\section{Literature Review and Hypothesis}

\subsection{Theory}

In agency theory, the owner of the company gives a mandate to someone who is later called a manager to run the company he owns. According to Jensen and Meckling (1976) in agency theory, there is separation of ownership, company control, separation of risk bearers, decision makers and control functions (Santoso \& Dhiyaul-Haq, 2017). Because of this separation, conflicts between company owners and managers often occur. This is due to a conflict of interest between managers and company owners where managers usually prioritize their own interests (Rizfani \& Lubis, 2019). In this study, agency theory limits problems to ISR activities and company reputation where through ISR activities it is expected to reduce conflicts of interest so that the company's reputation is well maintained. 
Companies in carrying out ISR are due to external social, political, economic and religious demands, so they need a balance in carrying out these demands from external parties. This is discussed in the theory of legitimacy. Legitimacy theory states that companies must take steps so that the company's activities and activities are accepted by the community (Hadinata, 2019). Therefore, companies must continuously convince the public that the company has carried out its activities in accordance with the norms and rules that exist in society (Hadinata, 2019). Suwaldiman (2013) states that company activities related to social activities in the community aim to gain legitimacy or community recognition regarding the company's existence so that the company can continue to operate (Hadinata, 2019). This rests on a social contract or license to operate from the community. If the community is not satisfied, the community can revoke the social contract against the company so that it can cause the company to not operate or close (Hadinata, 2019). In this study, the legitimacy theory is used as the basis for the ISR disclosure. ISR is a CSR disclosure in accordance with an Islamic perspective (Cahya, 2018). ISR is one way of disclosing the condition of a company entity in full in an Islamic context where based on Islamic perceptions, the public needs to know information or disclosure from a company according to their needs based on the principles of Islamic law because the public has the right to know various information about organizational activities (Cahya, 2018).

Regarding financial performance, Jumingan (2011) states that financial performance is a description of the company's financial condition in a period which includes raising funds through indicators of measuring capital adequacy, liquidity, and profitability (Hadinata, 2019). According to Brigham \& Houston (2007), the most important thing in financial performance is to analyze its performance which consists of comparing the performance of the company with companies in a similar plot and evaluating the company's financial position (Hadinata, 2019). Financial performance analysis activities consist of reviewing data, calculating, measuring, interpreting, and providing solutions to company finances in a certain period. In this study, the disclosure of financial performance uses company profits (Wang et al., 2020). The company's profit itself can be measured through Return On Equity (ROE) (Wang et al., 2020). ROE is the ratio between earning after tax (EAT) and total equity. According to Kasmir (2009), Return On Equity or ROE can be formulated as follows (Winarno, 2019). operating profit after tax

$\mathrm{ROE}=$ $\mathrm{x} 100 \%$

Equity

In the Islamic perspective, concern for others has been written in the Koran and Al-Hadith. The main purpose of doing business in Islam is to get blessings from Allah SWT (Indrawaty \& Wardayati, 2016). According to Maali (2006) that in doing business, it is aimed at getting profit, but the business must be in accordance with the Sharia taught (Indrawaty \& Wardayati, 2016). According to Haniffa (2002), the objectives of the ISR are (1) as a form of accountability to Allah SWT and society, (2) increasing transparency of business activities by presenting relevant information by paying attention to the spiritual needs of Muslim investors or sharia compliance in decision making (Rizfani \& Lubis, 2019). Hartini 2018 states that ISR is a measure of the implementation of sharia social performance and corporate responsibility to stakeholders consisting of customers, employees, investors, suppliers, competitors, government, competitors, and the community (Hartini, 2018). Arshad et. all (2012) states that social activities such as ISR can improve a company's reputation as well as financial performance (Hadinata, 2019). Therefore it is necessary to measure the company's success in implementing the ISR. The success of a company in implementing the ISR is measured using the ISR index (Cahya, 2018; Hadinata, 2019; Indrawaty \& Wardayati, 2016; Rizfani \& Lubis, 2019; Santoso \& Dhiyaul-Haq, 2017). Fahri and Trisnawati (2013) state that the ISR Index contains a compilation of CSR standard items set by AAOIFI (Accounting and Auditing Organization for Islamic Financial Institutions) which are then further developed by researchers according to Islamic entities. In this study, the measurement of the ISR index is based on research conducted by Haniffa (2002), Haniffa \& Hudaib (2007), and Othman et al. (2009) where the ISR index consists of 6 themes, namely the theme of finance, products, human resources, social, environment, and corporate governance (Cahya, 2018; Hadinata, 2019; Indrawaty \& Wardayati, 2016; Rizfani \& Lubis, 2019; Santoso \& Dhiyaul-Haq, 2017).

The company's reputation is one of the factors that affect financial performance. Fombrun (2002) states that a company's reputation is a collective representation of the company's past actions and future prospects which explains how major resource providers interpret a company's initiative and assess its ability to deliver valuable results (Solikhin \& Lubis, 2019). Wartick (1992) defines company reputation as an aggregation of the perceptions of a single stakeholder about how well the organization's response meets the demands and expectations of many organizational stakeholders (Solikhin \& Lubis, 2019). According to Ponzi et. all (2011) company reputation is a construction that involves the disciplines of economics, marketing, management, psychology, and sociology (Ji et al., 2017). Fombrun \& Riel (2003) stated that company reputation is a strategic resource to create a positive company image and competitive advantage. Keh \& Xie (2009) define a company's reputation as an overall evaluation of the extent to which a company is substantially "good" or "bad" (Solikhin \& Lubis, 2019). In addition, Barnett et. all. (2006) stated that reputation can be considered as an attribute that distinguishes one company from another or according to Walsh \& Beatty, 2007 as a reaction to company services, communication activities, and 
interactions with companies and / or company representatives (Solikhin \& Lubis, 2019). This study uses the results of measurements conducted by Picton and Broderick (2001) to measure company reputation (Hardiani, 2016). There are six factors used in measuring the company's reputation, namely: (1) dynamic - the indicators are pioneers, attracting attention, being active and goal-oriented (2) cooperative - the indicators are friendly, liked, make others happy, and have good relationships with others (3) wise - the indicators are wise, smart, persuasive, well organized (4) character - ethical / ethical, good reputation, and respectable indicators (5) success - indicators of good financial performance, and self-confidence and (6) able to hold back - the indicators are strict, keep secret and be careful (Hardiani, 2016).

Berger \& Lucmann (1966) argue that business ethics represents an arbitrary concept, because what makes behavior "ethical" may not be fixed or intrinsic, but rather an interpretation imposed on behavior. Thus, "business ethics" can be seen as a social construction, the result of individual or collective interpretation of certain social phenomena through discourse in certain settings (Dalton \& dela Rama, 2017). Based on a normative perspective, business ethics is related to principles, values and norms whereas based on a descriptive perspective, business ethics is related to codes, standards of behavior and compliance systems (Ferrell et al., 2019). Based on this, business ethics is part of the guidelines for ethical behavior in a business entity. Kaptein (2004) investigated the codes of conduct of the 200 largest companies in the world in 2001 and found that $58 \%$ of the 200 largest companies in the world had a code of conduct (Wijaya et al., 2018). The code of conduct includes product and service quality (67\%), compliance with local laws and regulations (57\%), protection of the natural environment $(56 \%)$, honesty $(50 \%)$, fairness $(45 \%)$, teamwork ( $43 \%)$, discrimination $(44 \%)$, intimidation (43\%), conflicts of interest $(52 \%)$, corruption $(46 \%)$, and cheating $(45 \%)$. In this study, business ethics is measured using the measurement results of Han Dongker et al. (2008) which identified 10 factors contained in a company code of ethics (Yahfizham, 2013).

In this study, the control variable used to analyze the influence of ISR disclosure, company reputation and business ethics on financial performance is the size of the company (Ullah et al., 2020; Wang et al., 2020), the company's own capital capacity. to fulfill its obligations called Debt to Equity Ratio (DER) and the proportion between debt owned and all assets (assets) owned is called the Debt to Asset Ratio (DAR) (Andhani, 2019; Effendy, 2017; Kurniasih \& Surachim, 2019).

This study will analyze the effect of Islamic Social Reporting Disclosure and company reputation on financial performance. This influence is moderated by business ethics. The conceptual framework of this study is shown in Figure 1.

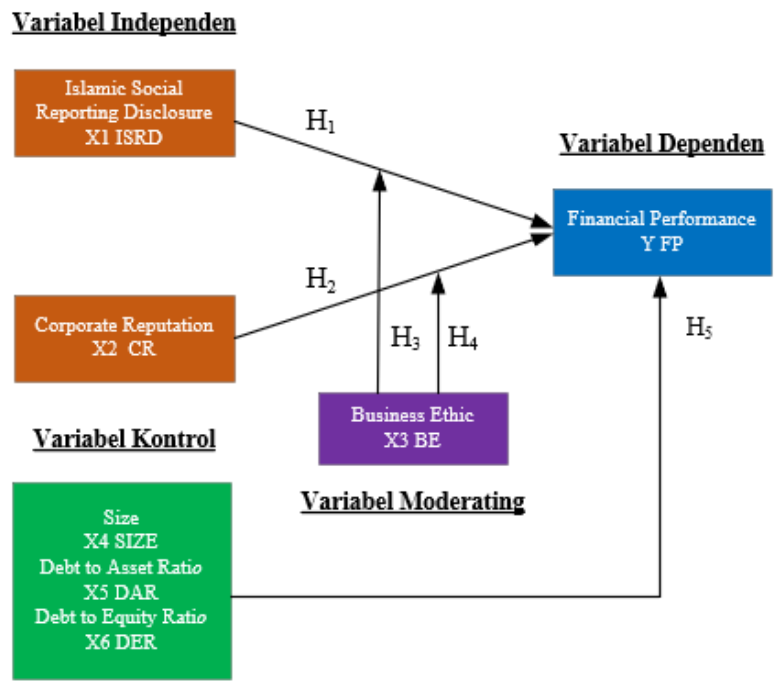

Figure 1. Research Conceptual Framework

\subsection{Hypothesis Development}

In the last few decades, CSR activities have grown tremendously. The government requires companies to carry out CSR activities. This is stated in Law No.40 of 2007 concerning Limited Liability Companies Chapter IV, article 66 paragraph 2c and Chapter V, article 74 related to social concerns (Asriati et al., 2016). Related to CSR itself, companies that carry out high CSR tend not to go bankrupt (Lin \& Dong, 2018) and avoid the risks that will occur to the company (Frederiksen, 2018). In an Islamic perspective, this CSR activity is in the form of Islamic Social Reporting (ISR) activities (Cahya, 2018; Hadinata, 2019; Indrawaty \& Wardayati, 2016; Rizfani \& Lubis, 2019; Santoso \& Dhiyaul-Haq, 2017). However, the results of research related to ISR have not been consistent. Companies that implement ISR according to Sharia have a better accounting system (Cahya, 2018), improve the 
company's image or reputation in the eyes of the public (Hadinata, 2019; Indrawaty \& Wardayati, 2016), and have a positive effect on corporate governance (Santoso \& Dhiyaul-Haq, 2017). However, in Islamic banking, the influence of ISR on financial performance in Islamic banking has a negative impact on Return of Assets (ROA) and profit (Hadinata, 2019). Other research states that ISR has no effect on Return of Assets (ROA) or profit in Sharia banking (Santoso \& Dhiyaul-Haq, 2017). Based on this, the hypothesis of the effect of ISR on financial performance is:

\section{H1: Islamic Social Responsibility (ISR) disclosure has a positive effect on financial performance}

The company's reputation is an aggregation of stakeholder perceptions about how well the organization's response meets the demands and expectations of many organizational stakeholders, creates a positive company image, creates competitive advantage, attributes that differentiate it from other companies, and evaluates how good or bad a company is based on stakeholder perceptions. (Solikhin \& Lubis, 2019). Companies that have a good and strong reputation have strong, sustainable, and profitable competitiveness for the company (Ali et al., 2020), have a positive impact on future financial performance (Kuranovic, 2018) and affect the success of relationships with customers (Ji et al., 2017; Walsh et al., 2016). Therefore, a good company reputation can improve the company's financial performance. Based on this, the hypothesis of the effect of company reputation on financial performance are:

H2: The company's reputation has a positive effect on financial performance

Research related to the effect of ISR on financial performance has not been consistent. Some of the effects have a positive impact (Cahya, 2018), have a negative impact (Hadinata, 2019) and have no impact at all (Santoso \& Dhiyaul-Haq, 2017). This study will try to strengthen the positive influence of ISR on financial performance by adding business ethics as a moderating variable because business ethics can improve the company's business continuity (Ramboarisata \& Gendron, 2019), keeping business activities in accordance with the rules (Vidgen et al., 2020), and maintain the attitude of employees in doing business so as not to harm the company (HernándezLópez et al., 2020). With business ethics, the activities of ISR are also carried out properly and maximally so that they can provide benefits to the company and stakeholders. Based on this, the hypothesis of the effect of ISR on financial performance as moderated by business ethics is:

H3: Moderation of business ethics strengthens the positive influence of Islamic Social Reporting Disclosure on financial performance.

A company in business life must have a good reputation in the eyes of its stakeholders. With a good reputation, the company can compete with other companies (Ali et al., 2020), the company's finances are healthy in the long term (Kuranovic, 2018), and the company will get success in doing business (Ji et al., 2017; Walsh et al., 2016). Many young companies, especially e-commerce on social media (Ji et al., 2017; Walsh et al., 2016) cause the need for a regulation in doing business. This study places business ethics as a moderating variable that affects company reputation. This needs to be done by young entrepreneurs in building their businesses. Business ethics is related to principles, values, norms, codes, standards and compliance systems in doing business (Ferrell et al., 2019). Companies that implement good business ethics are expected to be able to compete fairly and sportsmanship in business. Companies that carry out business ethics will have a long-term business (Ramboarisata \& Gendron, 2019), always go according to the corridor (Vidgen et al., 2020), and the company will benefit (Hernández-López et al., 2020). Based on this, the hypothesis of the effect of company reputation on financial performance as moderated by business ethics is:

H4: Moderation of business ethics reinforces the positive influence of company reputation on financial performance.

\section{Methedology of Research}

This type of research used in this research is explanatory survey research (explanatory research). According to Singarimbun and Efendi (1995), explanatory research is research that explains causal relationships and hypothesis testing (Amerieska \& Nurhidayah, 2014). This study uses secondary data from the annual reports of Islamic banks in Indonesia in the 2012-2016 period. The population in this study were all Islamic banking in Indonesia. The sampling method used in this study is the saturated sample method selected based on the following criteria: (1) Islamic banking is registered with the OJK (Financial Services Authority) and publishes annual financial reports consistently for the period 2012-2016; (2) Islamic banking that issues annual financial reports using the rupiah currency. The sample used was 11 Islamic banks so that the number of banks studied was 2012-2016. 
The dependent variable used in this study is the company's financial performance report over a certain period of time. This report is the result of achievement that is influenced by the company's operational activities in utilizing the resources owned and proxied by the ratio of profitability and profit, namely return of equity (ROE) where profit is measured after tax (Earning After Tax / EAT) divided by total equity multiplied by one hundred percent (Winarno, 2019). The independent variables in this study consist of Islamic Social Reporting disclosure and company reputation. The ISR measurement uses the ISR Index which contains a compilation of CSR standard items set by AAOIFI (Accounting and Auditing Organization for Islamic Financial Institutions) which is then further developed by researchers according to Islamic entities. This research measures the ISR index based on research conducted by Haniffa (2002), Haniffa \& Hudaib (2007), and Othman et al. (2009) where the ISR index consists of 6 themes, namely the theme of finance, products, human resources, social, environment, and corporate governance (Cahya, 2018; Hadinata, 2019; Indrawaty \& Wardayati, 2016; Rizfani \& Lubis, 2019; Santoso \& Dhiyaul-Haq, 2017). Measurement of ISR uses dimensions and indicators made by Maali et. all. (2006) using the dummy method for Islamic banks in six countries (Santoso \& Dhiyaul-Haq, 2017). ISR disclosure that uses content analysis by combining narrative, value, and visual images. Smith (2007) and Olesen (2012) state that in measuring the content analysis of the ISR disclosure, the researchers used a rating of 0,1,2,3 (Susanti \& Nurhayati, 2014). The number of indicators used for measurement was 43 disclosure items. The formula used is as follows.

\section{Disclosure level $=\underline{\text { Jumlah score disclosure yang dipenuhi }}$}

Jumlah score maksimum

If the disclosure is irrelevant then it is given a weight of 0 , narration / story with limited comments, illustrations are short and not quality and delivered in 1 sentence given a weight of 1 , using a detailed narrative (without the support of visual images or numbers) is categorized as medium quality because disclosure has given certain Islamic corporate (IC) information given a weight of 2, expressed using a narrative and supported by several numbers (monetary and non-monetary) or visual images are considered to be of the highest quality information, because information is supported by visual images so numbers are given a weight of 3 . In the company's reputation, the measure used is to adopt the theory of Picton and Broderick, 2001, which explains that there are 6 (six) factors that can be used to measure the reputation of a company with 20 indicators, namely (1) dynamic - the indicator is a pioneer, interesting attention, active and goal-oriented (2) cooperation $\mathrm{f}$ - indicators are friendly, liked, make others happy, and have good relationships with others (3) wise - indicators are wise, intelligent, persuasive, well organized (4) character - indicators are ethical / ethical, good reputation, and respectable ( 5) success - the indicators are good financial performance, and confident and (6) able to hold back - the indicators are strict, keeping secrets and being careful (Hardiani, 2016). Penilaiannya menggunakan dummy dimana jika indikator tersebut terdapat di dalam annual report perusahaan akan diberi nilai 1 dan jika tidak terdapat di dalam annual report perusahaan maka diberi nilai 0 (Hardiani, 2016). The moderating variable in this study is business ethics. Business ethics is measured using the measurement results of research by Han Dongker et al (2008) which identify 10 factors contained in a company code of ethics consisting of (1) accountability (2) courage (3) excellence (4) Fairness (5) Honesty (6) Honor (7) Respect (8) Trust (9) Integrity (10) Responsibility (Yahfizham, 2013). The assessment uses a dummy where if the company implements the indicator it is given a value of 1 and if it is not given a value of 0 . The variables to control financial performance consist of company size (Ullah et al., 2020; Wang et al., 2020), the company's own capital capacity, and the proportion between debt and wealth (Andhani, 2019; Effendy, 2017; Kurniasih \& Surachim, 2019). Firm size is measured from the company's total assets at the end of the year (Wang et al., 2020). To measure Firm Size, the formula used is Firm Size = Ln (Total Asset) (Ullah et al., 2020). Regarding the company's own capital capacity, the measurement uses the Debt to Equity Ratio (DER) which is a ratio that describes debt to equity in company funding. The formula for DER is (Andhani, 2019; Effendy, 2017; Kurniasih \& Surachim, 2019):

$$
\mathrm{DER}=\frac{\text { Total Debt }}{\text { Total Equity }}
$$

The proportion between debt and wealth is measured by Debt to Asset Ratio (DAR). The formula for DAR is (Andhani, 2019; Effendy, 2017; Kurniasih \& Surachim, 2019).

$$
\mathrm{DAR}=\frac{\text { Total Debt }}{\text { Total Assets }}
$$

The research model is moderated regression analysis (Winarni, 2018) with the following equation:

$\mathrm{Y}=\mathrm{a}+\mathrm{b}_{1} \mathrm{X}_{1}+\mathrm{b}_{2} \mathrm{X}_{2}+\mathrm{b}_{3} \mathrm{X}_{1} \mathrm{X}_{3}+\mathrm{b}_{4} \mathrm{X}_{2} \mathrm{X}_{3}+\mathrm{b}_{5} \mathrm{X}_{4}+\mathrm{b}_{6} \mathrm{X}_{5}+\mathrm{b}_{7} \mathrm{X}_{6}+\mathrm{e}$

where $\mathrm{Y}$ is Financial performance (FP) in Return of Equity (ROE), a is constant, b is regression coefficient, $\mathrm{X} 1$ is Islamic Social Reporting Disclosure (ISRD), X2 is company reputation (CR), X3 is business ethics (BE), $\mathrm{X} 4$ is the size of the company (Size), X5 is the Debt to Asset Ratio (DAR) and X6 is the Debt to Equity Ratio (DER).

\section{Result}

\subsection{Descriptive Statistics}

The results of descriptive statistical testing consisting of minimum, maximum, mean and standard deviation of the 
dependent, independent, moderation and control variables in this study can be seen in table 1 . Table 1. Descriptive Statistics

\begin{tabular}{|c|c|c|c|c|c|}
\hline Variabel & $\mathrm{N}$ & Minimum & Maximum & Mean & Std. Deviation \\
\hline X1 (ISRD) & 55 & 18.00 & 62.00 & 42.3818 & 9.90228 \\
\hline $\mathrm{X} 2(\mathrm{CR})$ & 55 & .05 & .80 & .4391 & .16824 \\
\hline X3 (BE) & 55 & .30 & .90 & .7327 & .14537 \\
\hline X1X3 & 55 & 9.00 & 55.80 & 31.4509 & 10.38605 \\
\hline $\mathrm{X} 2 \mathrm{X} 3$ & 55 & .03 & .63 & .3242 & .14288 \\
\hline X4 (Size) & 55 & 27.57 & 32.00 & 29.7266 & 1.26822 \\
\hline X5 (DAR) & 55 & .11 & .93 & .4983 & .33739 \\
\hline X6 (DER) & 55 & .13 & 13.84 & 4.1678 & 3.44981 \\
\hline $\mathrm{Y}$ & 55 & -.49 & .58 & .0471 & .15157 \\
\hline Valid N (listwise) & 55 & & & & \\
\hline
\end{tabular}

Source: Primary Data Processed, 2018

Table 1 shows that the minimum value of the variable X1 (ISRD) is 18 , the maximum is 62 , the average value is 42.38 and the standard deviation is 9.90 . For variable $\mathrm{X} 2(\mathrm{CR})$, the minimum value is 0.05 , the maximum is 0.80 , the average is 0.43 and the standard deviation is 0.16 . Then, the minimum value of the variable $\mathrm{X} 3(\mathrm{BE})$ is 0.30 , the maximum is 0.90 , the average is 0.73 and the standard deviation is 0.14 . Regarding X4 (Size), the minimum value is 27.57 , the maximum value is 32.00 , the average is 29.72 , and the standard deviation is 1.26 . The minimum value of X5 (DAR) is 0.11 , the maximum value is 0.93 the average is 0.49 and the standard deviation is 0.33 . For the variable X6 (DER), the minimum value is 0.13 , the maximum is 13.84 , the average is 4.16 , and the standard deviation is 3.44 .

\subsection{Hypothesis Testing Results}

The results of data normality testing on the dependent, independent, moderation and control variables in this study can be seen in Figure 2 .

Figure 2 shows that the data collection results spread around the diagonal lines and follow the direction of the diagonal lines. The results on the histogram graph show a normal distribution pattern, it can be concluded that the data is normally distributed.

\section{Normal P-P Plot of Regression Standardized Residual}

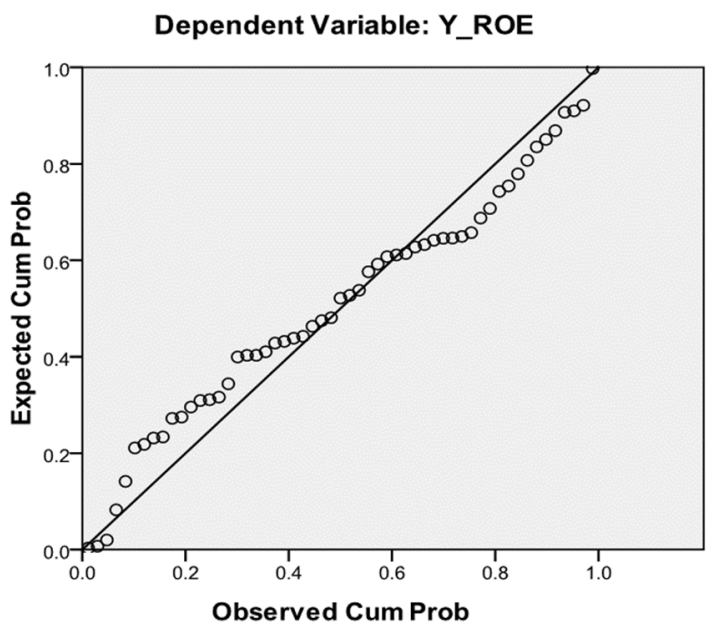

Figure 2. Grafik Histogram Uji Normalitas

Autocorrelation or self-correlation is a condition where there is a correlation of a variable with the variable itself, either with the variable value in the previous period or the variable value in the period after. In this study, autocorrelation testing used the Durbin Watson statistical test, namely by comparing the calculated statistical value (Napitupulu, 2017). The results of the auto correlation test using the Durbin Watson can be seen in the table below. 
Table 2. Durbin Watson's Autocorrelation statistical test

\begin{tabular}{|c|c|}
\hline Model & Durbin-Watson \\
\hline 1 & 0,528 \\
\hline
\end{tabular}

Source: results of SPSS Processing 22

Table 2 shows the results of the Durbin Watson (DW) autocorrelation statistical test in this study were 0.528 , with a significance level of $5 \%$, the $\mathrm{dU}$ value was 1.77 and $\mathrm{dL}$ was 1.37 . Based on the decision making, it is stated that DW $0.528<\mathrm{dL} 1.37$.

The results of testing the linear regression model used in this study to analyze the relationship between the dependent, independent, moderation and control variables can be seen in table 3 .

Table 3. Regression model test results - Anova

\begin{tabular}{|l|l|l|l|l|l|l|}
\hline \multicolumn{2}{|c|}{ Model } & \multicolumn{1}{c|}{ Sum of Squares } & $\mathrm{df}$ & Mean Square & \multicolumn{1}{c|}{ F } & Sig. \\
\hline \multirow{3}{*}{1} & Regression & .471 & 8 & .059 & 3.515 & $.003^{\mathrm{a}}$ \\
\cline { 2 - 8 } & Residual & .770 & 46 & .017 & & \\
\cline { 2 - 8 } & Total & 1.240 & 54 & & & \\
\hline
\end{tabular}

a. Predictors: (Constant), DER, X3, lnTA, X2, X1, DAR, X2X3, X1X3

b. Dependent Variable: Y ROE

Table 3 shows the significance of the linear regression model test results with ANOVA is 0.003 . This shows that the significance value is $0.003<0.05$.

The results of testing the effect of Islamic Social Reporting Disclosure and company reputation on financial performance which is moderated by business ethics can be seen in table 4 .

Table 4. The influence of Islamic Social Reporting Disclosure, company reputation on financial performance moderated by business ethics

\begin{tabular}{|c|c|c|c|c|c|c|}
\hline & & Unstandar & Coefficients & Standardized & & \\
\hline & & B & Std. Error & & & \\
\hline 1 & (Constant) & .551 & 1.028 & & .536 & .594 \\
\hline & X1 (ISRD) & -.033 & .016 & -2.170 & -2.112 & .040 \\
\hline & $\mathrm{X} 2$ (CR) & -.671 & .704 & -.745 & -.953 & .345 \\
\hline & X3 (BE) & -2.008 & 1.016 & -1.926 & -1.977 & .054 \\
\hline & $\mathrm{X} 1 \mathrm{X} 3$ & .049 & .020 & 3.352 & 2.468 & .017 \\
\hline & $\mathrm{X} 2 \mathrm{X} 3$ & .24 & .809 & .249 & .327 & .745 \\
\hline & X4 (Size) & .034 & .020 & .287 & 1.750 & .087 \\
\hline & X5 (DAR) & .023 & .123 & .052 & .189 & .851 \\
\hline & X6 (DER) & .003 & .011 & .079 & .322 & .749 \\
\hline
\end{tabular}

Source: results of SPSS Processing 22

Table 4 shows the results of the test of the effect of Islamic Social Reporting Disclosure, the company's reputation on financial performance which is moderated by business ethics by (1) The influence of X1 (ISRD) on financial performance has a regression coefficient value of -0.033 with a significance value of 0.04 (2) The effect of X2 (CR) on financial performance has a regression coefficient value of -0.671 with a significance value of 0.345 (3) The influence of the X3 (BE) variable on financial performance has a regression coefficient value of -2.008 with a significance value of 0.054 (4) The influence of X1 (ISRD) on Financial performance which is moderated X3 (BE) has a regression coefficient value .049 with a significance value 0.017 (5) The effect of X2 (CR) on moderated financial performance X3 (BE) has a regression coefficient value .24 with a significance value 0.745 . Regarding the relationship between control variables and financial performance, the effect of X4 (Size) on financial performance has a regression coefficient value of 0.034 with a significance value of 0.087 , the effect of X5 (DAR) on financial performance has a regression coefficient value of 0.023 with a significance value of 0.851 , and the influence of X6 (DER) on financial performance has a regression coefficient of 0.003 with a significance value of 0.749 .

Based on the results of the test on the effect of Islamic Social Reporting Disclosure, the company's reputation on financial performance is moderated by business ethics as shown in table 4, the form of the linear regression equation is as follows. 


$$
\mathrm{Y}=0,551-0,033 \mathrm{X} 1-0,671 \mathrm{X} 2-2,008 \mathrm{X} 3+0,49 \mathrm{X} 1 \mathrm{X} 3+0,264 \mathrm{X} 2 \mathrm{X} 3+0,034 \mathrm{X} 4+0,023 \mathrm{X} 5+0,003 \mathrm{X} 6
$$

\subsection{Discussion}

\subsubsection{Descriptive Statistics}

The results of the descriptive statistics table 1 in this study indicate that all data from X1 (ISRD), variable X2 (CR), variable X3 (BE), variable X4 (Size), variable X5 (DAR), and variable X6 (DER) have a value good representation of the whole data and spread evenly. This is because all variables have an average value that is greater than the standard deviation value. This shows that in all variables there are low data deviations so that the data distribution is normally distributed and unbiased.

\subsubsection{Hypothesis test}

The results of the normality test in Figure 2 show that the data from the dependent, independent, moderated and control variables are normally distributed because they spread around the diagonal line. The results of the autocorrelation test or self-correlation using the Durbin Watson statistical test in table 2 show that the magnitude of the Durbin Watson (DW) value has a positive autocorrelation value because the correlation coefficient value is greater than zero. At the 5\% significance level, the dU value is 1.77 and $\mathrm{dL}$ is 1.37 . In this study, the level of DW $<\mathrm{dL} 1.37$ is 0.528 , thus positive autocorrelation occurs. The results of the significance test of the linear regeri model shown in table 3 indicate that the regression model created can be used in this study because the significance value is less than $5 \%$, which is equal to 0.003 so that this regression model can be used in finding the relationship and its influence on the independent, moderation and control variables. the dependent variable.

The results of the partial regression test in table 4 which analyzes the effect of Islamic Social Reporting Disclosure and company reputation on financial performance moderated by business ethics show that the partial effect of variable X1 (ISRD) on financial performance and the effect of X1 (ISRD) on financial performance is moderated X3 (BE) has a significant effect on financial performance. Therefore, the first hypothesis related to Islamic Social Responsibility (ISR) disclosure has a positive effect on financial performance and the third hypothesis regarding moderation of business ethics strengthens the positive effect of Islamic Social Reporting Disclosure on financial performance is accepted. However, the influence of ISRD on financial performance in this study is not as expected. The results of this study are in line with the research of Bart et. all (2012), Peng \& Yang (2014), Sari et. all (2016), Rumengan et. all (2017) where social performance or ISRD has a negative effect on the company's financial performance (Hadinata, 2019). The population in this study were Islamic banks. According to Putranto \& Kewal (2014), Islamic banking in carrying out its operations emphasizes the social aspects of the bank, namely "less profit, more sense". Sharia banking is willing to operate with a small profit, but behind that it provides greater environmental and social benefits (Hadinata, 2019). Therefore, due to the existence of financial expenditures from Islamic banks to carry out ISRD while the income is small due to the principle of taking small profits, ISRD has a negative impact on Islamic bank finances. The effect of business ethics as a moderating variable on ISRD has an impact on strengthening the regression coefficient value of 0.082 . This shows that business ethics has a positive influence on the implementation of ISRD. These results are in accordance with research conducted by Ramboarisata \& Gendron (2019) where business ethics can improve the company's business continuity in a sustainable manner, which means that business ethics increases financial performance so that companies can be sustainable (Ramboarisata \& Gendron, 2019). Companies that carry out good business ethics, all activities carried out will be able to run well so that they can improve the company's financial performance and the company can be sustainable.

The partial test results on the other 2 (two) hypotheses show that the influence of the variable X2 (CR) on financial performance and the moderating effect of the variable X3 (BE) on X2 (CR) is not significant because the significance value is $>0.05$. This shows that the second hypothesis related to company reputation has a positive effect on financial performance, and the fourth hypothesis related to moderation of business ethics which strengthens the positive effect of company reputation on financial performance is rejected. The influence of company reputation on financial performance shows different results from research conducted by Ali et al (2020) and Kuranovic (2018). In this study, a high company's reputation provides strong, sustainable, and profitable competitiveness for the company (Ali et al., 2020), which has a positive impact on future financial performance (Kuranovic, 2018). However, in this study the company's reputation in Islamic banking had a negative impact. It is possible that Islamic banking in enhancing its reputation must pay a lot of money because people are not familiar with the Islamic banking system so that its financial performance decreases because Islamic banking in carrying out its operations emphasizes the social aspects and provides greater environmental and social benefits (Hadinata, 2019). Then related to business ethics, this can strengthen the effect of business reputation on financial performance where there is an increase in the value of the regression coefficient of 0.911 . Like the moderating effect of business ethics on ISRD, business ethics has a positive influence on the implementation of company reputation. Business ethics represents the concept of making "ethical" behavior perhaps impermanent or intrinsic (Dalton \& dela Rama, 2017). Business ethics is also related to principles, values, norms, codes, standards of behavior and compliance systems (Ferrell et al., 2019). Companies that have and implement good business ethics 
will also increase their company's reputation. Keh \& Xie (2009) state that a company's reputation as an overall evaluation of the extent to which a company is substantially "good" or "bad" (Solikhin \& Lubis, 2019). A company's reputation can be considered as an attribute that differentiates one company from another or as a reaction to company services, communication activities, and interactions with companies and / or company representatives (Solikhin \& Lubis, 2019). If the company does not have good business ethics, it is possible that the reaction from customers to the company is not good and it can reduce the company's reputation so that it can reduce the company's financial performance because no one wants to cooperate with the company anymore because of its bad business ethics.

\section{Conclusion}

The results of this study indicate that the Islamic Social Reporting Disclosure variable and the Islamic Social Reporting Disclosure variable which are moderated by business ethics have a significant effect on financial performance. In addition, business ethics as a moderating variable strengthens the influence of Islamic Social Reporting Disclosure on financial performance. The variable company reputation and corporate reputation variable which are moderated by business ethics do not significantly influence financial performance. In company reputation, business ethics as a moderating variable also strengthens the influence of company reputation on financial performance. The Islamic Social Reporting Disclosure variable in Islamic banking has a negative effect on financial finance because Islamic banking carries out its operations emphasizing the social aspects and providing greater environmental and social benefits so that the costs incurred for Islamic Social Reporting Disclosure activities are more and do not affect financial income. Syariah banking. The company's reputation also has a negative impact on the financial performance of Islamic banking. Sharia banking spends substantial funds in enhancing the company's reputation so that it is better known to the public so that it has an impact on Islamic banking financial spending. However, Islamic banking that practices business ethics can strengthen the Islamic Social Reporting Disclosure and the reputation of the banking company. This shows that business ethics can have a positive impact on every company activity so that the company gets financial and sustainable improvements.

\section{References}

Ali, I., Ali, M., Grigore, G., Molesworth, M., \& Jin, Z. (2020). The moderating role of corporate reputation and employee-company identification on the work-related outcomes of job insecurity resulting from workforce localization policies. Journal of Business Research, 117(December 2017), 825-838. https://doi.org/10.1016/j.jbusres.2019.02.060

Amerieska, S., \& Nurhidayah. (2014). Analisis Faktor - Faktor Yang mempengaruhi Kinerja Kemitraan Bisnis PT PLN (Studi Kasus Pada Kemitraan PT. PLN dengan AKLI Wilayah Kota Malang). Jurnal Manajemen Dan Akuntansi, 1(April), 1-12.

Andhani, D. (2019). Pengaruh Debt To Total Asset Ratio (DAR) dan Debt To Equity Ratio (DER) Terhadap Net Profit Margin (NPM) Serta dampaknya terhadap Harga Saham pada Perusahaan Elektronik di Bursa Efek Tokyo tahun 2007-2016. Jurnal SEKURITAS (Saham, Ekonomi, Keuangan Dan Investasi), 3(1), 45. https://doi.org/10.32493/skt.v3i1.3262

Asriati, R., Ulfah, P., \& Setyorini, C. T. (2016). Analisis Perbandingan Komponen Islamic Social Reporting ( ISR ) Pada Bank Syariah Antara Negara Indonesia dan Malaysia. Simposium Nasional Akuntansi XIX, Lampung, 1997, 1-24

Bruna, M. G., \& Nicolò, D. (2020). Corporate reputation and social sustainability in the early stages of start-ups: A theoretical model to match stakeholders' expectations through corporate social commitment. Finance Research Letters, 35(December 2019), 101508. https://doi.org/10.1016/j.frl.2020.101508

Budiono, A. (2017). Penerapan Prinsip Syariah Pada Lembaga Keuangan Syariah. Law and Justice, 2(1), 54-65. https://doi.org/10.23917/laj.v2i1.4337

Cahya, B. T. (2018). Diskursus Islamic Social Reporting Sebagai Akuntabilitas Berbasis Syariah. Madania: Jurnal Kajian Keislaman, 22(No.1), 49-62.

Charfeddine, L., Najah, A., \& Teulon, F. (2016). Socially responsible investing and Islamic funds: New perspectives for portfolio allocation. Research in International Business and Finance, 36, 351-361. https://doi.org/10.1016/j.ribaf.2015.09.031

Consulting, E. (2020). Islamic Finance Country Index-IFCI 2019. In Global Islamic Finance Report 2019.

Dalton, B., \& dela Rama, M. (2017). Business Ethics in Korea: Chaebol Dynastic Practices and the Uneven Transition From a Market to an Entrepreneurial Mode of Exchange. In The Political Economy of Business Ethics in East Asia: A Historical and Comparative Perspective. Elsevier Ltd. https://doi.org/10.1016/B9780-08-100690-0.00005-1

Darus, F., Ahmad Shukri, N. H., Yusoff, H., Ramli, A., Mohamed Zain, M., \& Abu Bakar, N. A. (2017). Empowering social responsibility of Islamic organizations through Waqf. Research in International Business and Finance, 42, 959-965. https://doi.org/10.1016/j.ribaf.2017.07.030 
Effendy, N. (2017). Integrasi Personal Balanced Scorecard, Psikologi Integral, dan Positive Organization Behaviour/ Scholarship sebagai Pendekatan Komprehensif di Perusahaan/Organisasi. Buletin Psikologi, 24(2), 87-99. https://doi.org/10.22146/buletinpsikologi.18822

Ferrell, O. C., Harrison, D. E., Ferrell, L., \& Hair, J. F. (2019). Business ethics, corporate social responsibility, and brand attitudes: An exploratory study. Journal of Business Research, 95(July), 491-501. https://doi.org/10.1016/j.jbusres.2018.07.039

Frederiksen, T. (2018). Corporate social responsibility, risk and development in the mining industry. Resources Policy, 59(March), 495-505. https://doi.org/10.1016/j.resourpol.2018.09.004

Hadinata, S. (2019). Islamic Social Reporting Index Dan Kinerja Keuangan Pada Perbankan Syariah Di Indonesia. EkBis: Jurnal Ekonomi Dan Bisnis, 2(1), 72. https://doi.org/10.14421/ekbis.2018.2.1.1099

Hardiani. (2016). Pengaruh Corporate Social Responsibility (CSR) Terhadap Brand Image (Citra Perusahaan) Studi Pada PT. Bank BRI Tbk (Persero) Cabang Makassar. Jurnal Imiah BONGAYA (Manajemen \& Akuntansi), Xix, 51.

Hartini, T. (2018). Analisis Pengaruh Firm Size dan Profitabilitas Terhadap Islamic Social Reporting (ISR) dengan Earning Growth Sebagai Variabel Moderating Pada Jakart Islamic Index (JII). Nurani, 18(1), 137-150.

Hasan. (2015). Prospek Pengembangan Perbankan Syariah Pendekatan Pasar. Tahkim, XI(2), 101-114.

Hernández-López, L. E., Álamo-Vera, F. R., Ballesteros-Rodríguez, J. L., \& De Saá-Pérez, P. (2020). Socialization of business students in ethical issues: The role of individuals' attitude and institutional factors. International Journal of Management Education, 18(1), 100363. https://doi.org/10.1016/j.ijme.2020.100363

Hidayat, Y. R. (2018). Analisis Peluang Dan Tantangan Lembaga Keuangan Syariah Untuk Meningkatkan Daya Saing Menghadapi Masyarakat Ekonomi Asean. Amwaluna: Jurnal Ekonomi Dan Keuangan Syariah, 2(2), 13-32. https://doi.org/10.29313/amwaluna.v2i2.3755

Indonesia, B. (2019). Laporan Ekonomi dan Keuangan Syariah Tahun 2019. fiskal.kemenkeu.go.id

Indrawaty, \& Wardayati, S. M. (2016). Implementing Islamic Corporate Governance (ICG) and Islamic Social Reporting (ISR) in Islamic Financial Institution (IFI). Procedia - Social and Behavioral Sciences, 219, 338343. https://doi.org/10.1016/j.sbspro.2016.04.042

Jan, A., Marimuthu, M., \& Mohd, M. P. bin. (2019). The nexus of sustainability practices and financial performance: From the perspective of Islamic banking. Journal of Cleaner Production, 228, 703-717. https://doi.org/10.1016/j.jclepro.2019.04.208

Ji, Y. G., Li, C., North, M., \& Liu, J. (2017). Staking reputation on stakeholders: How does stakeholders' Facebook engagement help or ruin a company's reputation? Public Relations Review, 43(1), 201-210. https://doi.org/10.1016/j.pubrev.2016.12.004

Kuranovic, V. (2018). RESEARCH ANALYSIS OF CHINA'S CORPORATE IDENTITY, IMAGE AND REPUTATION Veslav Kuranovic, Vilnius Gediminas Technical University. 9(1), 1-8.

Kurniasih, S., \& Surachim, A. (2019). Debt to Equity Ratio (DER) dan Return On Asset (ROA) untuk Meningkatkan Harga Saham. Strategic: Jurnal Pendidikan Manajemen Bisnis, 18(2), 44. https://doi.org/10.17509/strategic.v18i2.17590

Lin, K. C., \& Dong, X. (2018). Corporate social responsibility engagement of financially distressed firms and their bankruptcy likelihood. Advances in Accounting, 43(August), 32-45. https://doi.org/10.1016/j.adiac.2018.08.001

Mulyaningsih, \& Hermina, T. (2017). Etika bisnis.

Napitupulu, L. A. B. (2017). Pengaruh Komitmen Organisasional, Motivasi Dan Kompetensi Terhadap Kinerja Manajerial Pada Rumah Sakit Swasta Di Kota Pekenbaru. Jurnal Online Mahasiswa Bidang Ilmu Ekonomi, $4(1), 338-352$.

Nguyen, T. H. H., Ntim, C. G., \& Malagila, J. K. (2020). Women on corporate boards and corporate financial and non-financial performance: A systematic literature review and future research agenda. International Review of Financial Analysis, 71, 101554. https://doi.org/10.1016/j.irfa.2020.101554

Pepis, S., \& de Jong, P. (2019). Effects of Shariah-compliant business practices on long-term financial performance. Pacific Basin Finance Journal, 53, 254-267. https://doi.org/10.1016/j.pacfin.2018.11.002

Petitjean, M. (2019). Eco-friendly policies and financial performance: Was the financial crisis a game changer for large US companies? Energy Economics, 80, 502-511. https://doi.org/10.1016/j.eneco.2019.01.028

Pokharel, K. P., Archer, D. W., \& Featherstone, A. M. (2020). The Impact of Size and Specialization on the Financial Performance of Agricultural Cooperatives. Journal of Co-Operative Organization and Management, 8(2), 100108. https://doi.org/10.1016/j.jcom.2020.100108

Ramboarisata, L., \& Gendron, C. (2019). Beyond moral righteousness: The challenges of non-utilitarian ethics, CSR, and sustainability education. International Journal of Management Education, 17(3), 100321. https://doi.org/10.1016/j.ijme.2019.100321

Rizfani, K. N., \& Lubis, D. (2019). Pengungkapan Islamic Social Reporting pada Perusahaan di Jakarta Islamic Index. Al-Muzara'ah, 6(2), 103-116. https://doi.org/10.29244/jam.6.2.103-116 
Rodhiyah. (2011). Etika Bisnis Dan Keadilan Konsumen. Forum (Semarang), 39(2), 67-74.

Santoso, A. L., \& Dhiyaul-Haq, Z. M. (2017). Determinan Pengungkapan Islamic Social Reporting pada Bank Umum Syariah di Indonesia. Jurnal Dinamika Akuntansi Dan Bisnis, 4(2), 125-142. https://doi.org/10.24815/jdab.v4i2.6421

Shakeela, A., \& Weaver, D. (2018). "Managed evils" of hedonistic tourism in the Maldives: Islamic social representations and their mediation of local social exchange. Annals of Tourism Research, 71(October 2017), 13-24. https://doi.org/10.1016/j.annals.2018.04.003

Shim, K. J., \& Yang, S. U. (2016). The effect of bad reputation: The occurrence of crisis, corporate social responsibility, and perceptions of hypocrisy and attitudes toward a company. Public Relations Review, 42(1), 68-78. https://doi.org/10.1016/j.pubrev.2015.11.009

Solikhin, A., \& Lubis, T. A. (2019). Kinerja Perusahaan Tinjauan Reputasi Perusahaan dan CSR. In Journal of Chemical Information and Modeling (Vol. 53, Issue 9). https://doi.org/10.1017/CBO9781107415324.004

Stefano, F., \& Kok, S. K. (2020). The holding behavior of Shariah financial assets within the global Islamic financial sector: A macroeconomic and firm-based model. Global Finance Journal, 100557. https://doi.org/10.1016/j.gfj.2020.100557

Susanti, E., \& Nurhayati, P. (2014). Faktor-Faktor Yang Mempengaruhi Islamic Social Reporting PerusahaanPerusahaan Yang Terdaftar Pada Indeks Saham Syariah Indonesia (Issi) Tahun 2011-2012. Faktor-Faktor Yang Mempengaruhi Islamic Social Reporting Perusahaan-Perusahaan Yang Terdaftar Pada Indeks Saham Syariah Indonesia (Issi) Tahun 2011-2012, 3(2), 1153-1161.

Uddin, G. S., Arreola Hernandez, J., Labidi, C., Troster, V., \& Yoon, S. M. (2019). The impact of financial and economic factors on Islamic mutual fund performance: Evidence from multiple fund categories. Journal of Multinational Financial Management, 52-53, 100607. https://doi.org/10.1016/j.mulfin.2019.100607

Ullah, A., Pinglu, C., Ullah, S., Zaman, M., \& Hashmi, S. H. (2020). The nexus between capital structure, firmspecific factors, macroeconomic factors and financial performance in the textile sector of Pakistan. Heliyon, 6(8), e04741. https://doi.org/10.1016/j.heliyon.2020.e04741

Vidgen, R., Hindle, G., \& Randolph, I. (2020). Exploring the ethical implications of business analytics with a business ethics canvas. European Journal of Operational Research, 281(3), 491-501. https://doi.org/10.1016/j.ejor.2019.04.036

Walsh, G., Schaarschmidt, M., \& von Kortzfleisch, H. (2016). Employees' Company Reputation-related Social Media Competence: Scale Development and Validation. Journal of Interactive Marketing, 36, 46-59. https://doi.org/10.1016/j.intmar.2016.05.001

Wang, S., Wang, H., Wang, J., \& Yang, F. (2020). Does environmental information disclosure contribute to improve firm financial performance? An examination of the underlying mechanism. Science of the Total Environment, 714(96), 136855. https://doi.org/10.1016/j.scitotenv.2020.136855

Wijaya, R. S., Indrayeni, \& Raflis, R. (2018). Pengaruh Kode Etik Terhadap Kinerja Keuangan Perusahaan. Menara Ekonomi, IV(1), 101-110.

Winarni, E. W. (2018). Teori dan Praktik Penelitian Kuantitatif dan Kualitatif Penelitian Tindakan Kelas (PTK) Research And Development (R\&D).

Winarno, S. H. (2019). Analisis NPM, ROA, dan ROE dalam Mengukur Kinerja Keuangan. Jurnal STEI Ekonomi, 28(02), 254-266. https://doi.org/10.36406/jemi.v28i02.254

Xia, D., \& Wang, X. Q. (2020). The Synergetic Impact of Environmental and Innovation Infromation Disclosure an Corporate Financial Performance: An empirical Study Based on China Coal Listed Companies. Technovation, 144.

Yahfizham. (2013). Model Penerapan Etika Teknologi Informasi Pada Organisasi ( Perusahaan ). Jurnal Iqra, 07(02), 76-87.

Yesuf, A. J., \& Aassouli, D. (2020). Exploring synergies and performance evaluation between Islamic funds and socially responsible investment (SRIs) in light of the Sustainable Development Goals (SDGs). Heliyon, 6(8), e04562. https://doi.org/10.1016/j.heliyon.2020.e04562

Zraková, D., Kubina, M., \& Koman, G. (2017). Influence of Information-communication System to Reputation Management of a Company. Procedia Engineering, 192, 1000-1005. https://doi.org/10.1016/j.proeng.2017.06.172 